\title{
Pengaruh Faktor Pengetahuan terhadap Konstruksi Identiti Dalam Talian Menerusi Penggunaan Facebook
}

\author{
JAMILAH MALIKI \\ Universiti Malaysia Sarawak \\ MOHD NOR SHAHIZAN ALI \\ Universiti Kebangsaan Malaysia
}

\begin{abstract}
ABSTRAK
Media sosial membolehkan individu mewujudkan identiti dalam talian untuk memaparkan identiti pilihan mereka. Individu bukan sekadar mengkonstruksi identiti di luar talian malah boleh mengkonstruk semula identiti secara dalam talian. Identiti dalam talian membenarkan individu berinteraksi dengan semua lapisan pengguna termasuk orang yang tidak dikenali. Walau bagaimanapun, kajian sebelum ini tidak mengkaji sumber peribadi yang perlu dimiliki oleh seseorang individu untuk membolehkannya mengkonstruk identiti dalam talian. Kajian lalu juga didapati kurang meneliti kepelbagaian identiti yang mungkin dikonstruksi dalam talian sama ada identiti unggul, sebenar ataupun identiti samaran. Kajian ini bertujuan untuk menganalisis faktor pengetahuan yang mempengaruhi pengguna media sosial apabila mengkonstruksi identiti dalam talian. Pengguna aktif Facebook dalam kalangan 400 penuntut di empat buah institusi pengajian tinggi dipilih sebagai responden kajian ini. Dapatan kajian menunjukkan bahawa terdapat hubungan yang signifikan antara faktor pengetahuan yang dimiliki oleh pengguna Facebook dengan konstruksi identiti dalam talian sama ada identiti unggul, sebenar dan samaran. Aspek yang mendasari struktur pengetahuan telah dikenal pasti sebagai pengetahuan am, pengalaman, penapisan bahasa, pengetahuan memuat naik, penapisan komen dan penulisan status merupakan aspek penting yang diambil kira oleh responden apabila mengkonstruk identiti dalam talian. Interaksi sosial di Internet memberi ruang kepada individu mencipta sendiri dan memaparkan identiti mengikut acuan yang diinginkan dan dipaparkan kepada umum.
\end{abstract}

Keywords: Identiti dalam talian, identiti sebenar, identiti samaran, identiti unggul, pengetahuan.

\section{Effects of Knowledge Factor towards the Construction of Online Identity through the use of Facebook}

\begin{abstract}
Social media allow individuals to create an online identity according to their own predilections. Individuals are able to construct their identity offline but they are also capable of reconstructing their online identity. The online identity allows people to interact with people of all walks of life, including strangers. Previous studies on identity construction have not examined the personal resources individual should possess before they are able to construct their identity online. Similarly, past studies have not thoroughly examined the different types of identity that may be portrayed online such as ideal, real, or fake identity. This study investigates the role of knowledge in influencing the construction of online identity among users of social media. A total of 400 active users of Facebook who are students of four institutions of higher learnings were selected as respondents for this study. The findings indicate that there is a significant relationship between knowledge of Facebook users with the different types of online identity. General knowledge, experience, filtering of language,
\end{abstract}


knowledge on how to upload, filtering comments, and writing of status are components of knowledge that a respondent employs to construct online identity. Social interaction on the Internet provides space and freedom for individuals to create, portray, and display their very own identity according to their preferences.

Keywords: Identity construction, online identity, real identity, fake identity, ideal identity, knowledge

\section{PENGENALAN}

Media sosial memudahkan orang ramai berkongsi gambar, pendapat, kejadian dan sebarang maklumat lain pada masa sebenar. Kemudahan ini telah memberi impak kepada kehidupan sosial manusia masa kini. Kelebihan media sosial ialah ia "memungkinkan interaksi dengan kumpulan orang, sama ada dikenali ataupun orang asing, dalam satu lokasi sama atau merentas sempadan geografi" (Chandler \& Munday, 2011, hlm. 397). Chandler dan Munday berhujah bahawa media sosial boleh dianggap sebagai tempat pertemuan virtual yang berfungsi sebagai medan pertukaran kandungan media dalam kalangan pengeluar dan pengguna. Pengguna dapat menyerlahkan kehadiran sosialnya (Short, Williams \& Christie, 1976). Kehadiran ini dipengaruhi oleh intimasi dan kesegeraan (immediacy). Dengan kata lain media sosial menggalakkan kesedaran dan penyertaan yang meruntuhkan tembok pemisah antara komunikasi bersemuka dengan komunikasi berantarakan media. Ini disebabkan semakin ramai orang menggunakan peranti seperti telefon pintar untuk berkomunikasi dengan orang lain sama ada dalam ruang yang sama ataupun berbeza tetapi pada masa yang serentak.

Menerusi media sosial sebegini, pemilik akaun bukan sahaja menjadi pengguna tetapi menjadi pengeluar mesej. Mesej ini terkandung dalam interaksi sosial yang dilakukan dengan rakan atau orang awam. Media sosial mengubah landskap media yang dahulunya hanya dimonopoli media tradisional. Kini pemilik akaun media sosial membuat keputusan untuk menentukan bahan yang akan dikemukakan dalam laman Facebook. Apabila ini berlaku, pengguna perlu memiliki sesuatu set perspektif yang dapat membimbingnya dalam mengolah mesej. Aufderheide (1997, hlm. 80) menjelaskan bahawa kandungan media dikonstruksikan dan media mengkonstruksikan realiti. Jenkins (2009) berhujah bahawa pengguna media sosial memerlukan pengetahuan dan kemahiran untuk melibatkan diri dalam media sosial. Pengetahuan bukan setakat dipelajari menerusi buku ataupun kelaskelas formal (Gergen \& Gergen, 1981). Pengetahuan menggunakan media sosial diperolehi daripada interaksi dengan orang lain. Interaksi dengan orang lain meningkatkan pengetahuan tentang bagaimana untuk menggunakan media sosial. Pengetahuan turut dipertingkatkan menerusi pengalaman melakukannya. Pengetahuan bukan formal yang diperolehi dalam interaksi sosial membantu seseorang itu memperbaiki kemahiran literasi media. Pemilik akaun Facebook akan mengolah maklumat dengan tujuan tertentu dengan pengetahuan yang dimiliki.

Kepelbagaian media sosial memudahkan pemilik sesuatu akaun untuk mewujudkan identitinya di Internet. Media sosial membolehkan pemilik akaun untuk memuat naik gambar, malah boleh menulis status serta pelbagai kemudahan lain lebih mendapat perhatian (Boyd, 2007). Semuanya ini membentuk identiti pemilik akaun media sosial dalam talian. Pemaparan identiti sebegini sudah menjadi sebahagian daripada gaya hidup manusia masa kini (Siti Ezaleila \& Azizah, 2010). Perubahan pemaparan identiti seperti yang dimaksudkan menuntut individu menggunakan media secara literasi. Ini kerana penggunaan media sosial bukan sahaja melibatkan amalan literasi berasaskan pengetahuan memahami dengan mengguna, bahkan melibatkan kemahiran membina dan berkongsi mesej 